\title{
Dactylorhiza hatagirea: A Critical Issue for Research and Development in Nepal
}

\author{
Manu Maya Magar ${ }^{\prime *}$, Shambhu Prasad Dhital ${ }^{1}$, Tetsuya Yamada ${ }^{2}$ and \\ Umed Kumar Pun \\ ${ }^{1}$ Nepal Agricultural Research Council, Khumaltaar, Lalitpur \\ ${ }^{2}$ Tokyo University of Agriculture and Technology, Tokyo, Japan \\ ${ }^{3}$ Himalayan Flora Enterprises Private Limited, Hattiban, Lalitpur \\ *Corresponding Author \\ manu.bdnarc@gmail.com
}

\begin{abstract}
Dactylorhiza hatagirea (D. don), commonly known as 'Panchaule' in Nepal, is a terrestrial orchid found in temperate to the alpine region. It is valued for its ornamental and medicinal use. It is collected haphazardly from nature due to high economic demand. However, its propagation is limited in nature due to its non-endospermous seeds requiring mycorhizal fungal association for germination. This limitation is leading to the extinction of this orchid from nature and has been enlisted as an endangered and threatened species. Its collection and trade are restricted but have been prioritized for research, conservation, and agro-technology development. As very few research has been reported in $D$. hatagirea, found in Nepal, intensive research, propagation, reintroduction, and commercial cultivation will help control the rhizome collection from nature and meet the economic demand. It will help in the identification and conservation of our local germplasm through its diversity study at the molecular and revenue generation through commercial cultivation under artificial conditions. In this review paper, we discuss the limited research and developments conducted in Dactylorhiza at various levels and ways forward for its research, conservation, and utilization. As the plant is valued for its biochemical constituents, modern biotechnological tools such as transcriptomics and metabolomics can be best utilized to explore the opportunities and increase its production and reintroduction through mass propagation for better commercialization and conservation.
\end{abstract}

\section{Keywords}

Dactylorhiza hatagirea flower, herbal medicine orchid, salep

\section{Introduction}

D. hatagirea is temperate to alpine, monocotyledonous, perennial, and terrestrial orchid valued for its ornamental and medicinal use. It is a habitat-specific and inherently slowgrowing species in nature (Agarwal et al., 2008) and poorly regenerating species because its seeds are microscopic and non-endospermous with undifferentiated embryos. It needs a mycorhizal association for germination, thus posing a significant concern for long-term survival in a natural condition (Warghat et al., 2013). The abundance and distribution ranges of orchid species have undergone dramatic declines in recent decades due to human activities, habitat fragmentation, habitat loss due to forest destruction and degradation in the Himalayas where $D$. hatagirea is judged critically endangered (Acharya and Rokaya 2010; Pant and Raskoti 2013). It has a high annual demand of approximately 5000 tons (Badola and Pal 2002), leading to over-exploitation of the species from wild habitat for trade by local inhabitants. Adhikari et al. (2018) reported that over-extraction for medicinal purpose and habitat degradation as two significant constraints for the decline in the population of $D$. hatagirea in India. It has been listed in Appendix II by the Convention on International Trade in Endangered Species of Wild Fauna and Flora (CITES), vulnerable species listed by the Conservation 
Assessment and Management Plan (CAMP) and threatened species by the International Union for Conservation of Nature (IUCN) (Samant et al., 2001). The Government of Nepal has prioritized research in $D$. hatagirea for developing agrotechnology in Nepal (DPR, 2006), and collection, trade, and rhizome processing has been banned according to Forest Act 1993 and Forest Regulation 1995. Despite government prioritization, as per reports, efforts for its conservation, research, and development, its cultivation has not yet begun as planned. Despite its high economic value, the government has not given much importance for its conservation and production technology development. Most of the research works are concentrated only in the documentation, but the need is to be concentrated on the conservation aspects. Conservation of plant species can be done both insitu as well as ex-situ. Accessing its existing genetic variability and multiplication through tissue culture can give better alternatives for its ex situ conservation and utilization as compared to its protection through the implication of laws restricting its collection and trade. There are various advances in biotechnological tools that can be used to study the genetic variability in the plants; many of them are yet to be employed in $D$. hatagirea. In this review, we are trying to cover the scientific works conducted in D. hatagireaand find remaining gaps, which indicate an urgent need for extensive genetic diversity study and establishing an in-vitro propagation technique for $D$. hatagirea found in Nepal for its long term conservation and utilization.

\section{Classification and Morphology}

Dactylorhiza hatagirea (D. don) belongs to the Orchidaceae family. The orchids have attracted the admiration of scientists, horticulturists, herbalists, and laypeople alike, and deserve the pride of place in any discussion on flowering plants among the ornamentals. Orchidaceae is believed to be the second-largest family of flowering plants after Asteraceae, with between 21,950 and 26,049 currently accepted species, grouped into 880 genera (World Checklist of Selected Plant Families, 2013). Nepal harbours 451 species of orchid belonging to 104 genera (Rajbhandari, 2015). Central Nepal harbours the highest number of orchid species (69 species) followed by east Nepal (58 species) and west Nepal (33 species) (Acharya and Rokaya, 2010). Among them, D. hatagirea is a terrestrial-grounddwelling perennial herb with erect, hollow and obtuse stem, bears palmately lobed rhizome, and lanceolate leaves with sheathing leaf-base (Fig.1a). The cylindrical and terminal spike bears rosy-purple flowers with green bracts. The inflorescence consists of a compact raceme with 25 to 50 flowers developed from axillary buds. Flowers are 1.7-1.9 cm long with a curved spur, and the dark purple-spotted lip of the flower is rounded and lobed (1 to 5). The structure of orchid flowers is unique among floral plants. The orchid flower typically has an outer whorl of three sepals, an inner whorl of three petals, two identical and one modified (Lip), and a single massive column (the gynostemium, composed of the male stamens attached to the female pistil) in the centre (Fig.1b). The plants store a large amount of water in their palmately lobed tuberous roots (Fig.1c) to survive in arid conditions (Chaurasia et al., 2007).

\section{Distribution}

The distribution of Dactylorhiza covers most of Europe, temperate Asia, North Africa, Japan, Aleutian Islands, and northern parts of North America with the highest species richness in north-western Europe, though only nine species of Dactylorhiza are endemic. D. hatagirea is distributed in Nepal, India, Bhutan, China, Mongolia, Pakistan, and Russia (Raskoti and Ale 2009; Sirohi et al., 2019). This Himalayan endemic medicinal orchid is also documented in Hindu Kush Himalaya range in terrestrial habitat from Western Himalaya (Afghanistan, Pakistan), India (Jammu and Kashmir, Himachal Pradesh, Uttarakhand, Sikkim), Bhutan, South-East China and Nepal (Hulma, Dolpa, Doti, Kaski, Gorkha, Rasuwa, Sindhupalchok, Dolakha) (Flora of China Editorial Committee, 2009) (Fig. 2). Its habitat is in grassland slopes in the sub-alpine and the alpine zones between $2800 \mathrm{~m}$ and $4200 \mathrm{~m}$ altitudes above the mean sea level (IUCN, 2004). The altitudinal range of habitat distribution of $D$. hatagirea in Annapurna Conservation Area is reported as 3200 to 3600 meters above sea level with abundance in the slope from $30^{\circ}$ to $60^{\circ}$ at north-east aspect (Ranpal 2009) and maximum species richness of total medicinal orchid is observed at an elevation 
of $1700 \mathrm{~m}$ above sea level (Acharya and Rokaya 2010). Hamayun Shaheen et al., (2019) recorded its abundance at $4150 \mathrm{~m}$ above sea level in Deosai National Park in Pakistan, and North-West facing steep slopes of Kardang in Ladakh and Shreenagar were found to have $D$. hatagirea as per Jagdish et al., 2018.

In Nepal, studies on orchids are mainly focused on their documentation (Bajracharya et al., 2003; Rajbhandari and Dahal 2004; Shakya and Shrestha

(a)

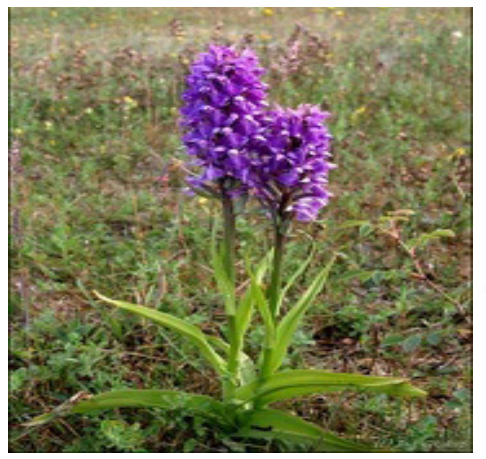

(b)

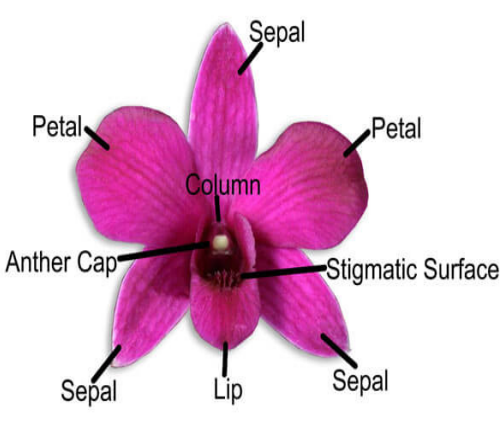

of awareness among the local community as significant causes of $D$. hatagirea decline in then Samagaun Village Development Committee (VDC) of Manaslu Conservation Area (MCA). Khadka et al., (2016) reported a density of 0.276 per $\mathrm{m}^{2}$ of $D$. hatagirea in Lete VDC of Mustang District, indicating the functional ecological status but unsatisfactory plant diversity, which suggested for immediate necessary actions for the conservation of the diversity in the study area. The

Fig.1. Morphology of $D$. hatagirea(a) aerial part of flowering plants, (b)name of each part of a flower, (c) rhizomes.

2007; Shresthaet al., 2007) and its medicinal uses (Shrestha 2000; Vaidya et al., 2000). However, there is less effort on a quantitative study on their distribution pattern along the elevation gradients because information on altitudinal species richness patterns can be highly instrumental for proper management and conservation of species (Grytnes 2003). Chettri and Gupta (2007) documented the presence of $D$. hatagirea at very low (less than 0.2 plant $\mathrm{m}^{2}$ ) population density growing above treeline in moist habitat only in Samar Lek site in upper Mustang. Gaire (2014) reported D. hatagirea as one of the most potential Medicinal and Aromatic Plants (MAPs) in the Sagarmatha National Park. Bhattarai et al., (2014) studied the availability and conservation status of $D$. hatagirea in Samagaun Village of Gorkha District located within the Manaslu Conservation Area (MCA). They reported a density of 2.18 individuals per $\cdot \mathrm{m}^{2}$ with frequency and abundance of $81.81 \%$ and 2.67 individuals per $\cdot \mathrm{m}^{2}$, respectively, indicating that the species is threatened in the study area. Pandey et al. (2016) also reported overgrazing of domestic animals, over-harvesting, and lack high potential of $D$. hatagirea to grow over large areas forming significant continuous distribution boundaries is affected due to anthropogenic activities (Warghat et al., 2012). However, Thakur et al. (2018) found the enhanced performance of $D$. hatagirea populations driven by disturbances. It suggested that food-deceptive species in small populations tend to reduce the probability of population extinction and have the capability to recover rapidly if conserved on time. It shows the need for systematic planning that incorporates local individuals' participation, prioritization of their views, and cooperation between local institutions, state agencies, researchers, and other stakeholders for the long-term management and commercial utilization.

\section{Phytochemical Study}

$D$. hatagirea is one of the highest valued orchids extensively used in traditional medicine as a farinaceous food and nerve tonic for sick, stomachache, headache, typhoid, effective in chronic diarrhoea, fever, general debility, in treating weakness in children and women, root powder is spread on wounds to control bleeding 


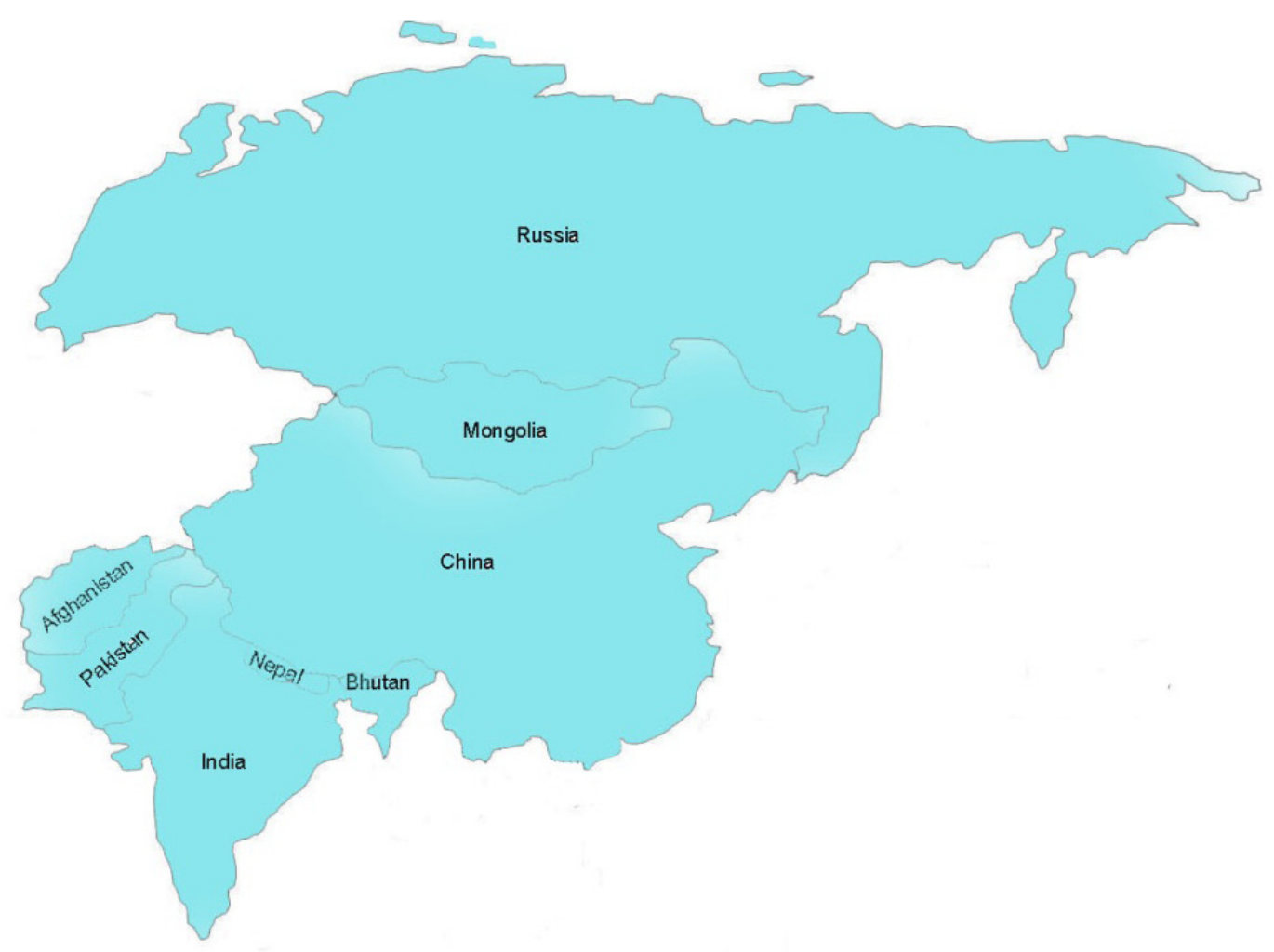

Fig. 2. Distribution of Dactylorhizahatagirea

Ref.: Raskoti and Ale (2009) and Flora of China Editorial Committee(2009)

(Watanabe et al., 2005; Baral and Kurmi 2006; Pant and Raskoti, 2013; Boladi et al., 2018 and Nand et al., 2018, Chamoli and Sharan, 2019, Magar et al., 2020). It is also considered an alternative source of salep used very commonly in Europe and is considered an essential aphrodisiac plant in Ayurveda, Siddha, Unani literature. Therefore, it is employed to enhance performance and to increase vigour and vitality (Pant and Rinchen, 2012).

It has different spectrums of antibacterial action as evidenced from the result of the various screening tests, indicates that the rhizome part of $D$. hatagirea is more effective than the aerial part against all tested organisms except $E$. coli (Ranpal 2009). At the same time, antifungal compounds are present, assumed from its ability to restrict symbiotic fungal growth inside the orchid cytoplasm (Shimura et al., 2007). Hydroalcoholic extracts were found effective against yeast induced pyrexia in rats (Srohi and Sagar, 2019).

The tubers contain a glucoside, a bitter substance, starch, mucilage, albumen, a trace of volatile oil, and ash (Dutta and Karn 2007). The primary chemical constituents are Dactylorhin A, B, C, D, and E; Dactylose A and B; and two kinds of lipid mixtures along with twelve other compounds in Panchaule found in Nepal (Kizuet al., 1999) (Table 1). Biochemicals from medicinal plants (e.g., Dendrobium plants, Bupleurum, Cactus fruits, Angelica Sinensis (Oliv.) Diels, Aloe barbadensis Miller, and Dimocarpus longan Lour have been found to show prominent bioactivities, including anti-tumour, antioxidant, anticoagulant, antidiabetic, radio-protection effect, antiviral, hypolipidemic and immuno modulatory activities (Xie et al., 2016).

The consumption of salep, prevalent in the traditional medicine of different societies and beliefs, has been effective in improving male 
sexual strength (Farnoosh and Riazi, 2007; Esteves et al., 2011). Thakur et al. (2007) reported improved libido in male rats when injected with aqueous salep extract, which is made from the rhizome of D. hatagirea. Yang et al., (2006) stated that consumption of natural antioxidants protects sperm cells against oxidative stress-induced by lysed cells and ultimately improves fertility. The therapeutic potential of $D$. hatagirea extract due to high antioxidant properties has also been reported by Sirohi et al. (2019). Similarly, the methanolic extract of $D$. hatagirea has been tested in 3T3-L1 cell lines under in vitro condition, which shows a non-toxic reaction on the cells indicating the presence of antidiabetic compounds (Alsawalh et al., 2019). The root extract of this orchid has a significant role in reducing blood glucose, lipid, and total protein in experimental diabetic rats, supporting its anti-diabetic properties (Choukarya et al., 2019).

Genetic factors, evolution, geographic variation, environmental conditions (i.e., harvest date, planting time), physiological variations (i.e., organ and leaf position), and developmental stage are known to affect the biosynthesis of the essential oil and other phytochemicals in Dactylorhiza (Rodrigues et al., $2013 \mathrm{a}, \mathrm{b}$ ). Thus, there is ample opportunity to produce desired phytochemicals through extensive research to utilize orchids for their varied medicinal uses.

\section{Genetic Diversity}

Effective conservation, management, recovery, and utilization of rare and endangered species can be achieved through variability analysis. Genetic diversity assessment provides the basis for in situ conservation and sustainable utilization of the plant genetic resources as the marked and robust differentiation among natural populations (Allnutt et al., 2003). Variation in the morphological characters is possible due to variations in topography, elevation, soil fertility, rainfall, and other climatic conditions, which are very specific to Himalaya (Kuniyal et al., 2002). Genetic diversity inherent in plants plays a significant role in the ability of a population to respond adaptively to environmental changes (Ayala and Kiger

Table 1. Chemicals found in Dactylorhiza hatagirea

\begin{tabular}{|c|c|c|c|c|}
\hline S. $\mathbf{N}$. & $\begin{array}{l}\text { Common } \\
\text { Name }\end{array}$ & Chemical Name & $\begin{array}{l}\text { Structural } \\
\text { Formula }\end{array}$ & $\begin{array}{c}\text { Molecular wt. (g/ } \\
\text { mol) }\end{array}$ \\
\hline 1 & $\begin{array}{l}\text { Dactylorhin } \\
\text { A }\end{array}$ & $\begin{array}{l}\text { (2R)-2- } \beta \text {-D-glucopyranosyloxy-2(2-methylpro- } \\
\text { pyl)butanedioic acid bis(4- } \beta \text {-D-glucopuranosy- } \\
\text { loxybenzyl)ester }\end{array}$ & $\mathrm{C}_{40} \mathrm{H}_{56} \mathrm{O}_{22}$ & 888.866 \\
\hline 2 & $\begin{array}{l}\text { Dactylorhin } \\
\text { B }\end{array}$ & $\begin{array}{l}(2 \mathrm{R}, 3 \mathrm{~S})-2-\beta-\mathrm{D} \text {-glucopyranosyloxy-3-hy- } \\
\text { drosy-2-(2-methylpropyl)butanedioic acid } \\
\text { bis(4- } \beta \text {-D-glucopyranosyloxybenzyl)ester }\end{array}$ & $\mathrm{C}_{40} \mathrm{H}_{56} \mathrm{O}_{23}$ & 904.865 \\
\hline 3 & $\begin{array}{l}\text { Dactylorhin } \\
\text { C }\end{array}$ & $\begin{array}{l}\text { (2R)-2- } \beta \text {-D-glucopyranosyloxy-2-(2-methylpro- } \\
\text { pyl) butanedioic acid }\end{array}$ & $\mathrm{C}_{14} \mathrm{H}_{24} \mathrm{O}_{10}$ & 352.336 \\
\hline 4 & $\begin{array}{l}\text { Dactylorhin } \\
\text { D }\end{array}$ & $\begin{array}{l}(2 \mathrm{R}, 3 \mathrm{~S})-2-\beta-\mathrm{D}-\mathrm{glucopyranosyloxy}-3-\mathrm{hy}- \\
\text { droxy-2-(2-mehtylpropyl)butanedioic acid } \\
\text { 1-(4- } \beta \text {-D-glucopyranosyloxybenzyl) ester }\end{array}$ & $\mathrm{C}_{27} \mathrm{H}_{40} \mathrm{O}_{17}$ & 636.6 \\
\hline 5 & $\begin{array}{l}\text { Dactylorhin } \\
\text { E }\end{array}$ & $\begin{array}{l}\text { (2R)-2- } \beta \text {-D-glucopyranosyloxy-2-(2-methyl pro- } \\
\text { pyl)butanedioic acid 1-(4- } \beta \text {-D-glucopyranosy- } \\
\text { loxybenzyl) ester }\end{array}$ & $\mathrm{C}_{27} \mathrm{H}_{40} \mathrm{O}_{16}$ & 620.60 \\
\hline 6 & Dactylose A & 1-deosy-1-(4-hydroxyphenyl)-L-sorbose & $\mathrm{C}_{12} \mathrm{H}_{16} \mathrm{O}_{6}$ & 256.254 \\
\hline 7 & Dactylose B & 1-deoxy-1-(4-hydroxyphenyl-L-tagatose & $\mathrm{C}_{12} \mathrm{H}_{16} \mathrm{O}_{6}$ & 256.254 \\
\hline
\end{tabular}

Source: Kizu et al., 1999 
1984). Morphological variability in plants, along with biochemical differences in protein and sugar levels, are essential parameters to study natural populations of rare plants, reflecting an adaptive feature of the species (Bhadula et al., 1981). Molecular markers are the essential tools to study the genetic diversity among different populations, which shows actual genetic differences existing between different populations and can overcome the environmental effects. Therefore, a comparative study on morphological, biochemical, and genetic diversity using molecular marker technique of the populations at different locations of Nepal can give a pleasant scenario of existing genetic variation of this orchid contributing to its conservation and utilization.

Warghat et al., (2012) studied morphological variation in 13 natural population of $D$. hatagirea in Ladakh and reported that phenotypic variation in morphological and horticultural traits could be utilized in its genetic improvement.Germplasm of $D$. hatageria collected from different nine geographical locations of the Garhwal Himalaya was grouped into two clusters based on their similarities and variations in morphology, biochemical parameters, and isoenzyme pattern (Chauhan et al., 2014). Localized distribution of D. hatagirea (Semwal et al., 2007), habitat fragmentation and population deterioration have increased mating opportunities between closely related individuals, resulting in loss of genetic diversity (Warghat et al., 2013). The low genetic diversity reduced the ability for evolution unless there were opportunities for immigration of new allelic diversity into future populations (Rinchen et al., 2012). Isoenzyme studies supported variability among different populations and suggested esterase isoenzyme as an excellent marker to study intra-population variations in $D$. hatagirea (Bhadula et al., 1996). Warghat et al. (2012) used 20 Random amplified polymorphic DNA (RAPD) markers and revealed low genetic variation within the population and moderate genetic differentiation among the $D$. hatagirea population in the cold desert of Ladakh. Thakur et al., (2013) also used 33 highly (99\%) polymorphic RAPD to study the genetic diversity in the D. hatagirea population collected from Himachal Pradesh, India reported the existence of tremendous variability among populations. Warghat et al. (2013) revealed a moderate level of genetic differentiation among D. hatagirea populations in Nubravalley, Ladakh, and supported the grouping of all 96 sample sizes of nine locations into two collections group using AMOVA of ISSR analysis.

Orchids make up the largest monocot family, but the molecular variation shaping this important biodiversity is still little understood (Givnish et al., 2015). The molecular basis of biodiversity can reside in amino-acid-sequence variation (Nielsen 2005) and regulatory divergence that triggers protein abundance shifts (Wray 2007), and these molecular components may evolve at different rates. The relatively rapid mutation rate and high frequency in the genome have made SSRs be popular markers for population genetics (Hsu et al., 2013; Huang et al., 2014 and Tsai et al., 2014), hybrid detection (Liao et al., 2012), linkage mapping, genetic fingerprinting (Chiouet al., 2012 and Tsai et al., 2013), evolutionary history (Ge et al., 2012 and Ge et al., 2015), and taxonomy (Ho et al., 2014) among various plant species. However, its use in D. hatagirea has not yet been documented. De novo transcriptome analysis of $D$. hatagirea revealed the presence of differentially expressed genes governing various metabolic pathways and stress tolerance (Dhiman et al., 2019).There exists a vast opportunity in transcriptomic of $D$. hatagirea, which can be used to reveal various aspects of its uses and values in human life.

\section{Plant Propagation}

D. hatagirea is temperate to alpine, monocotyledonous, perennial, and terrestrial orchid valued for its ornamental and medicinal use. It is a habitat-specific and inherently slowgrowing species in nature (Agarwal et al., 2008) and poorly regenerating species because seeds are microscopic and non-endospermous with undifferentiated embryos posing a prime concern for long-term survival in a natural condition (Warghat et al., 2013). It has a prolonged rate of vegetative propagation and very poor seed germination in nature that is 0.2 to $0.3 \%$ (Vij 2002). It has a high annual demand of approximately 5000 tons (Badola and Pal 2002), leading to overexploitation of the species from wild habitat due 
to illegal collection and trade by local inhabitants. In the wake of ongoing habitat loss coupled with global climate change, plant conservation through reserves is not expected to keep pace with the extinction rates projected this century (Swarts and Dixon 2009). An integrated conservation approach is needed to augment in situ conservation, including the recovery, use, and long-term storage of mycorrhizal fungi for symbiotic seed germination (Swarts 2007). Development of a symbiotic germination method of orchid seeds by Knudson (1884-1958), formulating Knudson B and C medium (Knudson 1922, 1946) was the first procedure for in vitro propagation of any plant in pure culture (Yam et al., 2009). Therefore, tissue culture can be one of the essential measures in exsitu conservation of terrestrial orchids (Jakobsone et al., 2007) through in-vitro mass multiplication as the desirable traits are perfectly preserved in the seedling population (Kesari et al., 2010). Besides, it also helps to produce a significant number of identical clones that can be raised from a single proto-corm, tuber segments, or shoot tip explants (Deb and Pongener 2012) to meet the increasing commercial demand.

The in vitro propagation of $D$. hatagirea is very difficult and slow as the process of seed germination to plantlets formation is very lengthy $(>1 \mathrm{yr})$, and very few numbers of in vitro raised plantlets can be obtained using green pod culture in M.S. medium (Vijet al.,1995). Regeneration using leaf segment, tuber segment culture, shoot bud culture, and green pod culture could not give any positive response (Agarwal et al., 2008). The in vitro seed germination is slow not only in D. hatagirea but also in the other species of Dactylorhiza. In D. ruthei, and $D$. praetermissa seeds started germinating after four months of culture, and only 20.0 to $25.0 \%$ germination was achieved in Norstog medium after eight months of inoculation (Vaasa and Rosenberg 2004). Rasmussen (1995) reported that most Dactylorhiza species require four years from germination to tuber/shoot formation, and two species (D. majalis, D. incarnata) may take up to 16 years to reach maturity. However, Aggarwal and Zettler (2010) found 100\% germination in $D$. hatagirea within ten days after sowing, and plants developed seedlings after three months. Giri and
Tamta (2012) also reported better germination on M.S. medium supplemented with peptone (1.0 $\mathrm{g} / \mathrm{L})$, morpholino ethane sulfonic acid (1.0 g/L), and activated charcoal $(0.1 \%)$.

In-vitro protocorm development and mass multiplication of this plant have helped in conservation and increasing biomass using solid M.S.media.Warghatetal.,(2014)madea successful attempt to culture immature seed embryos of D. hatagirea for developing protocorms, shoot regeneration and mass multiplication. They reported seed germination within one week on L.D. and TP039 media supplemented with $\mathrm{MnSO} 4$ as an essential component and observed $22 \%-23 \%$ of protocorm formation within 17 days of culture on L.D. medium. The multiple shoot formation was observed in shorter duration on M.S. medium supplemented with $3 \mathrm{mg} / \mathrm{L}$ IBA and $1 \mathrm{mg} / \mathrm{L}$ Kand the growth and multiplication in 28 to 30 days of incubation followed by successful hardening and transplantation to the greenhouse in the potting mixture.

Popli et al. (2016) optimized liquid M.S. media for increasing the biomass of endangered $D$. hatagirea and reported that the growth and development of plantlets with the maximum number of shoots, shoot length, number of roots, maximum root length, and maximum biomass occurred on M.S. medium supplemented with indole-3-butyric acid (IBA) and 6-benzyl amino purine (BAP) within 25 to 32 days of incubation. Liquid medium was reported to increase biomass four times as compared to solid media, which could be used as a platform for its conservation and mass propagation. At the same time, Giri and Tamta (2012) reported using different auxins treatments to obtain $D$. hatagirea at a lower elevation, and it can be enhanced by standardizing more concentration regimes of auxins and suitable environmental conditions at a lower elevation.

There are very few reports on reintroducing in vitro propagated species of medicinal orchids to natural habitat (Aggarwal and Zettler 2010; Lesar 2012.), or their cultivation is always collected from the wild for trade. Symbiotic germination has practical merit for both conservation and horticulture, but it remained an under utilized tool for orchids in our context. Aggarwal and Zettler 
(2010) reported a successful reintroduction of $D$. hatagirea seedlings grown from mycorrhizal fungi inoculated seeds, which resulted in 100\% germination within ten days of sowing, and healthy protocorms were obtained after 40 days, seedlings with well-developed roots, tubers and leaves were obtained after three months. The fungi isolated from the mature plants were characterized using molecular techniques. To substitute for the habitat protection and species recovery, it is crucial to identify and reintroduce over-exposed species through its multiplication using tissue culture.

\section{Conclusion}

D. hatagirea has been categorized as endangered and prioritized for its research and conservation by the Government of Nepal. However, there are fewer efforts made to exploit the modern biotechnological tools for its research, conservation, and utilization. In-vitro mass propagation of this orchid and their reintroduction in the natural condition can be a good initiative for its in-situ conservation. At the same time development of successful agro-technology for its cultivation in commercial-scale under $e x$ situ conditions can fulfil both the medicinal and floricultural sectors. The use of molecular marker technology can give a good idea on the genetic diversity of $D$. hatagirea found in Nepal, and conservation efforts can be directed accordingly. Biomolecules present in the plant make it of high value. Therefore, intensive research on the biochemical constitution of the medicinal plants deserves special attention.There is very little documented information regarding genes related to essential metabolites and their expression. The development of trait-specific molecular markers will help in the identification of diversity in populations. Latest biotechnological tools like transcriptomics and metabolomics can be utilized to understand the biosynthetic pathwaysfor essential metabolites from this orchid. This will help in better utilization for medicinal and therapeutic purposes. If research is focused on this sector, panchaule can be one of the promising high-value products shortly for people living in the mountains of Nepal.

\section{References}

Acharya, K.P. and Rokaya, M.B. 2010. Medicinal
Orchids of Nepal: are they well protected? Our Nature 8:82 -91.

Adhikari, D., Reshi, Z., Datta, B. K., Samant, S.S., Chettri, A., Upadhaya, K., Shah, M.A., Singh, P.P., Tiwary, T., Majumdar, K., Pradhan, A., Thakur, M.L., Salam, N., Zahoor, Z., Mir, S.H., Kaloo, Z.A., and Barik., S.K.2018. Inventory and characterization of new populations through ecological niche modelling improve threat assessment. Current Science 114 (3):0468-0595)

Agarwal, A., Khokhar, D., and Vishwanath. 2008. Conservation through in vitro propagation of a critically endangered medicinal plant, Dactylorhizahatagirea (D. Don) Soo. In: Reddy MV (ed). Wildlife Biodiversity Conservation.Daya Publishing House, pp.294-299.

Aggarwal, S., and Zettler, L.W., 2010. Reintroduction of an endangered terrestrial orchid, Dactylorhizahatagirea (D.Don) Soo, assisted by symbiotic seed germination: first report from the Indian subcontinent. Nature and Science 8:139145.

Allnutt, T.R., Newton, A.C., Premoli, A., and Lara, A. 2003. Genetic variation in the threatened South American conifer Pilgerodendronuviferum (Cupressaceae), detected using RAPD markers. Biological Conservation 114:245-253.

Alsawalha, M., Al-Subaei, A.M., Al-Jindan, R.Y., Bolla, S.R., Sen, D., Balakrishna, J.P., Ravi, P.K., Reddy Gollapalli, S.S., Veeraraghavan, V.P., Pillai, A.A., Joseph, J.P., Salahuddin, M., Mohan, S.K. 2019. Antidiabetic activities of Dactylorhiza hatagirea leaf extract in the 3T3-L1 cell line model. Pharmacognosy Magazine 15 (2):212-7

Ayala, F.J. and Kiger, J. A. 1984.Modern Genetics, Benjamin/Cummings, Menlo Park, Calif, USA, 2nd edition.

Badola, H.K., and Pal, M., 2002. "Endangered Medicinal plant in Himachal Pradesh."Current Science 83(7):797-798.

Bajracharya, D.M., Subedi, A. and Shrestha, K.K. 2003.Eriapokharensisspnov (Orchidaceae): A new species from Nepal Himalaya. The journal of the Orchid Society of India 17:1-4.

Balodi, K.N., Purohit, M.V., Shridhar, V., and Arunachalam, K. 2018. Ethno-medicinal Uses of 
Various Plants Species among the Jaad Bhotiya Community of Uttarakhand, Western Himalaya. Ethno Medicine 12(3):189-197

Baral, S.R. and Kurmi, P.P. 2006.A Compendium of Medicinal Plants in Nepal. Mass Printing Press, Kathmandu.

Bhadula, S.K., Singh, A. Lata, H., Kuniyal, C. P., and Purohit, A. N. 1996."Genetic resources of Podophyllum hexandrum Royle, an endangered medicinal species from Garhwal Himalaya, India," Plant Genetic Resources Newsletter 106:26-29.

Bhadula, S.K., Thapliyal, A. P and Purohit, A. N. 1981 "Seed protein, esterase, and acid phosphatase in Rhododendron species from different altitudes in Garhwal Himalaya."Indian Journal of Experimental Biology 19:199-200.

Bhattarai, P., Pandey, B., Gautam, R.K., and Chhetri, R. 2014. Ecology and Conservation Status of Threatened Orchid Dactylorhiza hatagirea (D. Don) Soo in Manaslu Conservation Area, Central Nepal. American Journal of Plant Sciences 5:34833491.

Chamoli, K.P., and Sharan, H., 2019. Ethno-medicinal properties of Dactylorhiza hatagirea in higher Himalayan villages of Rudraprayag district of Uttarakhand. Journal of Mountain Research 14 (2):85-88 .http://jmr.sharadpauri.org

Chauhan, R.S., Nautiyal, M.C., Vashistha, R.K., and Prasad, P. 2014. Morphobiochemical Variability and Selection Strategies for the Germplasm of Dactylorhiza hatagirea (D. Don) Soo: An Endangered Medicinal Orchid. Journal of Botany Pp.1-5.

Chaurasia, O. P., Ahmed, Z, and Ballabh, B. 2007.In Ethnobotany and Plants of Trans-Himalaya. Satish Serial Publishing House, Delhi, India

Chhetri, H.B. and Gupta, V.N.P. 2007. A survey of nontimber forest products (NTFPS) In upper Mustang. Scientific World 5(5):89-94.

Chiou, C.Y., Chiang, Y.C., Chen, C.H., Yen, C.R., Lee, S.R., Lin, Y.S., and Tsai, C.C. 2012 Development and characterization of 38 polymorphic microsatellite markers from an economical fruit tree, the Indian jujube. American Journal of Botany 99:199-202.

Choukarya, R., Choursia, A., Rathi, J. 2019. In Vivo and
In Vitro Antidiabetic Activity of Hydroalcoholic Extract of Dactylorhiza Hatagirea Roots: An Evaluation of Possible Phyto-constituents. Journal of Drug Delivery and Therapeutics 9 (6-s):76-1. Available from: http://www.jddtonline.info/index. php/jddt/article/view/3752

Deb, C.R., and Pongener, A., 2012.Studies on the in vitro regenerative competence of aerial roots of two horticultural important Cymbidium species. Journal of Plant Biochemistry and Biotechnology 6:1-7.

Dhiman, N., Sharma, N.K., Thapa, P., Sharma, I., Swarnkar, M.K., Chawla, A., Shankar, R. and Bhattacharya, A. 2019. De novo transcriptome provides insights into the growth behavior, resveratrol, and trans-stilbenes biosynthesis in Dactylorhiza hatagirea - An endangered alpine terrestrial orchid of western Himalaya. Scientific Reports 9:13133.

DPR. 2006. Plants of Nepal: Fact Sheet. Ministry of Forest and Soil Conservation, Government of Nepal, Thapathali, Kathmandu, Nepal.

Dutta, I.C. and Karn, A.K. 2007. Antibacterial Activities of some traditional used Medicinal plants of Daman, Nepal. T.U., IOF \& Com Form, Pokhara, Nepal.

Esteves, S.C., Miyaoka, R, and Agarwal, A. 2011. An update on the clinical assessment of the infertile male. Clinics 66:691-700.

Farnoosh, R., and Riazi, A., 2007.A compositional study on two current types of salep in Iran and their rheological properties as a function of concentration and temperature. Food Hydrocolloids 21:261-265.

Gaire, D., 2014. Status, Distribution, Conservation, and Use Value of Medicinal and Aromatic Plants (MAPs) in Sagarmatha National Park, Nepal. Journal of Forest and Environmental Science 30(3):253-258.

Ge, X.J., Hsu, T.W., Hung, K.H., Lin, C.J., Huang, C.C., Huang, C.C., Chiang, Y.C. and Chiang, T.Y. 2012. Inferring multiple refugia and phylogeographical patterns in Pinus massoniana based on nucleotide sequence variation and fingerprinting. Plos One 7:e43717.

Ge, X.J., Hung, K.H., Ko, Y.Z., Hsu, T.W., Gong, X., Chiang, T.Y. and Chiang, Y.C. 2015. Genetic 
divergence and biogeographical patterns in Amentotaxu sargotaenia species complex. Plant Molecular Biology Reporter 33:264-280.

Giri, D., and Tamta, S., 2012. Propagation and conservation of Dactylorhiza hatagirea (D.Don) Soo, an endangered alpine orchid. African Journal of Biotechnology 11:12586-12594.

Givnish, T.J., Spalink, D., Ames, M., Lyon, S.P., Hunter, S.J., Zuluaga, A., Iles, W.J.D., Clements, M.A., Arroyo, M.T.K., Leebens-Mack, J., Endara, L., Kriebel, R., Neubig, M.K., Whitten, W.M., Williams, N.H. and Cameron, K.M. 2015. Orchid phylogenomics and multiple drivers of their extraordinary diversification. Proceedings of the Royal Society of London B. Biological Sciences 282:20151553.

Grytnes, J.A., 2003. Species-richness patterns of vascular plants along seven altitudinal transects in Norway. Ecography 26: 291-300. Winkel, G.V., 2006. Finding orchids in Nepal. The Orchid Review, 114:188-191.

Ho, C.S., Shih, H.C., Liu, H.Y., Chiu, S.T., Chen, M.H., Ju, L.P., Ko, Y.Z., Shih, Y.S., Chen, C.T., Hsu, T.W. and Chiang, Y.C. 2014. Development and characterization of 16 polymorphic microsatellite markers from Taiwan cow-tail fir, Keteleeriadavidiana var. formosana (Pinaceae), and cross-species amplification in other Keteleeriataxa. BMC Res Notes 7:255.

Hsu, T.W., Shih, H.C., Kuo, C.C., Chiang, T.Y. and Chiang, Y.C. 2013.Characterization of 42 microsatellite markers from poison ivy, Toxicodendron radicans (Anacardiaceae). International Journal of Molecular Sciences 14: 20414-20426.

Huang, C.L., Ho, C.W., Chiang, Y.C., Shigemoto, Y., Hsu, T.W., Hwang C.C., Ge, X.J., Chen, C., Wu, C.H., Huang, H.J., Gojobori, T., Osada, N. and Chiang, T.Y. 2014.Adaptive divergence with gene flow in incipient speciation of Miscanthus floridulus/Sinensis complex (Poaceae).The Plant Journal 80:834-847.

IUCN. 2004. National Register of Medicinal and Aromatic Plants. International Union for Nature Conservation Nepal, Kathmandu, Nepal.

Jagdish, S., Joginder, S., and Tewari, V.P., 2018. Screening and Evaluation of Superior Chemotypes of Podophyllum hexandrum Royle from Different Geographical Locations of North-west Himalayas. Journal of Plant Chemical and Ecophysiology 3(1): 1021 .

Jakobson, G., Dapkūnienè, S., Cepurīte, B. and Belogrudova, I. 2007. The conservation possibilities of endangered orchid species of Latvia and Lithuania. Monographs of Botanical Gardens (European Botanic Gardens Together Towards the implementation of Plant Conservation Strategies). Baltic Botanic Gardens 1: 65-68.

Kesari, V., Das, A., and Rangan, L. 2010.Effect of genotype and auxin treatments on rooting response in stem cuttings of CPTs of Pongamia pinnata, a potential biodiesel legume crop. Current Sciences 98 (9):1234-1237.

Khadka, C.B., Hammet, A. L., Singh, A., Balla, M. K. and Timilsina, Y. P. 2016. Ecological status and diversity indices of Panchaule (Dactylorhiza hatagirea) and its associates in Lete village of Mustang district, Nepal. BankoJanakari 26(1):4552.

Kizu, H., Kaneko, E., and Tomimori, T. 1999. Studies on Nepalese crude drugs - XXVI.Chemical constituent of Panchaunle, the root of Dactylorhiza hatagirea D. Don. Chemical and Pharmaceutical Bulletin 47(11):1618-1625.

Knudson, L., 1922. Nonsymbiotic germination of orchid seeds. Botanical Gazette: pp.1-25

Knudson, L., 1946. A nutrient for germination of orchid seeds. American Orchid Society Bulletin 15:214217.

Kuniyal, C. P., Bhadula, S.k. and Prasad, P. 2002. Morphological and biochemical variations among the natural populations of Aconitum atrox (Bruhl) Muk. (Ranunculaceae). Journal of Plant Biology.29:(1):91-96.

Liao, P.C., Tsai, C.C., Chou, C.H., and Chiang, Y.C. 2012.Introgression between cultivars and wild populations of Momordicacharantia L. (Cucurbitaceae) in Taiwan. International Journal of Molecular Sciences 13:6469-6491.

Magar, S.B., Bhandari, P. and Ghimire, S.K. 2020. Ethno-medicinal survey of plants used by Magar (Kham) community, Rolpa district, Western Nepal. Ethnobotany Research \& Applications 19:18 
Nand, K., and Naithani, S., 2018. Ethnobotanical uses of wild medicinal plants by the local community in the Asi Ganga sub-basin, Western Himalaya. Journal of Complementary Medicine Research 9(1):34-46

Nielsen, R., 2005. Molecular signatures of natural selection. Annual Review of Genetics 39:197-218.

Pandey, B., Timilsina, A., Pandey, B., Thapa, C.L., Nepali, K.B., Neupane, P., Thapa, R., Gaire, S.K., and Siwakoti, M. 2016.Peoples' Perception and Conservation of Dactylorhiza hatagirea (D. Don) Soó in Manaslu Conservation Area, Central Nepal. American Journal of Plant Sciences 7:1662-1672.

Pant, B., and Raskoti, B.B., 2013. Medicinal Orchid of Nepal. Himalayan Map House Pvt. Ltd., Kathmandu.

Pant, S., and Rinchen, T., 2012.Dactylorhizahatagirea: a high-value medicinal orchid. Journal of Medicinal Plants Research 6:3522-3524.

People, D., Sharma, S., and Sood, H. 2016.Optimization of Liquid MS Medium for Enriching Biomass of Dactylorhiza hatagirea. National Academy of Agricultural Science. 34(5):1271-1276.

Rajbhandari, K.R., and Dahal, S., 2004. Orchids of Nepal: a checklist. Botanica Orientalis 4:89-106.

Rajbhandari, K.R., 2015.A Handbook of the Orchids of Nepal. Department of Plant Resources, Thapathali, Kathmandu, Nepal. p. 168.

Ranpal, S., 2009. An Assessment of Status and Antibacterial Properties of Dactylorhiza hatagirea in Annapurna Conservation Area, a Case Study of Paplekharka, Lete VDC, Mustang. Master's Dissertation, Institute of Forestry, Tribhuvan University, Kathmandu.

Raskoti, B.B., and Ale, R., 2009. The Orchid of Nepal. Kathmandu

Rasmussen, H.N., 1995. Terrestrial orchids from seed to mycotrophic plant. Cambridge, UK: Cambridge University Press.

Rinchen, T., Pant, S., and Anwar, M., 2012. Population census of critically endangered Dactylorhiza hatagirea (D. Don) Soó in Suru valley, (cold desert region, Jammu and Kashmir, India) International Journal of Biodiversity and Conservation 4(9):332335.
Rodrigues, L., Povoa, O., Teixeira, T., Figueiredo, A.C., Moldao, M., and Monteiro, A. 2013a.Trichomes micromorphology and essential oil variation at different developmental stages of cultivated and wild-growing Menthapulegium L. populations from Portugal. Industrial Crops and Products 43:692-700.

Rodrigues, L., Povoa, O., Van den Berg, C., Figueiredo, A.C., Moldao, M., and Monteiro, A. 2013b. Genetic diversity in Menthacervina based on morphological traits, essential oils profile, and ISSRs markers. Biochemical Systematics and Ecology 51:50-59.

Samant, S.S., Dhar, U. and Rawal, R.S. 2001. Himalayan Medicinal Plants- Potential and Prospects (eds) Samant, S. S., Dhar, U. and Palni, L. M. S. Gyanodaya Prakashan, Nainital, India, 166-184.

Semwal, D.P., Pardha, P., Saradhi, Nautiyal, B.P and Bhatt, A.B. 2007. Current status, distribution, and conservation of rare and endangered medicinal plants of Kedarnath Wildlife Sanctuary, Central Himalayas, India. Current Science 92(12):17331738 .

Shaheen, H., Ibrahim, M., and Ullah, Z., 2019. Spatial Patterns and Diversity of the Alpine Flora of Deosai plateau, Western Himalayas. Pakistan Journal of Botany. 51(1): 205-212.

Shakya, L.R., and Shrestha, M.R., 2007.Two new taxa of Orchidaceae from central Nepal. Edinburgh Journal of Botany 64:1-5.

Shimura, H., Matsuura, M., Takada, N., and Koda, Y. 2007. An antifungal compound involved in symbiotic germination of Cypripedium macranthos var. rebunense (Orchidaceae). Phytochemical 68:1442-1447.

Shrestha, M.R., Shakya, L.R. and Ghimire, S.K. 2007.A new species of Malaxissolander ex Swartz (Orchidaceae) from Dolpa, Nepal. Pleione 1:6-7.

Shrestha, R., 2000.Some medicinal orchids of Nepal. The Himalayan plants, can they save us? Proceeding of Nepal-Japan joint symposium on conservation and utilization of Himalayan medicinal resources (Eds. T. Watanabe, A. Takano, M.S. Bista, and H.K. Saiju), Society for the Conservation and Development of Himalayan Medicinal Resources (SCDHMR), Subedi, A. 2003.Orchid flora of Seti and Marsyangdi river valleys of central 
Nepal. Central Department of Botany, Tribhuvan University, Kirtipur. (M.Sc. Thesis)

Sirohi, B., Sagar, R. 2019. Antipyretic Activity of Hydroalcoholic Extract of Dactylorhiza Hatagirea Roots \& Lavandula Stoechas Flowers on Brewer's Yeast Induced Pyrexia in Wistar Rats. Journal of Drug Delivery and Therapeutics 9(4-A):701-4. Available from: http://www.jddtonline.info/index. php/jddt/article/view/3553

Sirohi, B., Sagar, R., and Kori, M.L., 2019. Comparative antioxidant activity of hydroalcoholic extract of roots of Dactylorhiza hatagirea and aerial part of Lavandula stoechas. Journal of Advanced Scientific Research 10(4):311-316.

Swarts, N. 2007.Integrated conservation of the rare and endangered terrestrial orchid Caladenia huegelii H.G. Reichb. Ph.D. Thesis. University of Western Australia, Perth.

Swarts, N.D. and Dixon K.W. 2009.Terrestrial orchid conservation in the age of extinction. Annals of Botany 104(3):543-556.

Thakur, D., Rathore, N., Sharma, M.K., and Chawla, A., 2018. Enhanced reproductive success revealed an essential strategy for the persistence of devastated populations in Himalayan food邓deceptive orchid, Dactylorhiza hatagirea. Plant Species Biology 33(3)191-202. DOI: 10.1111/1442-1984.12205

Thakur, M., and Dixit, V.K., 2007. Aphrodisiac activity of Dactylorhiza hatagirea (D.Don) Soo in male Albino rats. Evidence-Based Complementary and Alternative Medicine 4(1):29-31.

Thakur, N., and Kaur, R., 2013. Molecular characterization of Dactylorhiza hatagirea (D. Don) Soo- A critically endangered medicinal orchid. International Journal of medicinal and aromatic plants 3(2):184-190.

Tsai, C.C., Chen, Y.K.H., Chen, C.H., Weng, I.S., Tsai CM, Lee SR, Lin, Y.S., and Chiang, Y.C. 2013. Cultivar identification and genetic relationship of mango (Mangifera indica) in Taiwan using 37 SSR markers. Scientia Horticulturae 164:196-201.

Tsai, C.C., Wu, P.Y., Kuo, C.C., Huang, M.C., Yu, S.K., Hsu, T.W., Chiang, T.Y. and Chiang, Y.C. 2014. Analysis of microsatellites in the vulnerable orchid Gastrodia flavilabella: the development of microsatellite markers and cross-species amplification in Gastrodia. Botanical Studies 55:72.

Vaasa, A., and Rosenberg, V., 2004. Preservation of the rare terrestrial orchid is in vitro. Acta Universitatis Latviensis ser. Biology 676:243-246.

Vaidya, B., Shrestha, M., and Joshee, N. 2000. Report on Nepalese orchid species with medicinal properties. The Himalayan plants, can they save us? Proceeding of Nepal-Japan joint symposium on conservation and utilization of Himalayan medicinal resources. Society for the Conservation and Development of Himalayan Medicinal Resources (SCDHMR), Japan. Pp. 146-152.

Vij, S.P., 2002. "Orchids and tissue culture: Current status, in the role of plant tissue culture in biodiversity conservation and economic development. Gyanodaya Prakashan, Nainital, India. Pp. 491-502.

Vij, S.P., Pathak, P. and Mahant, K.C. 1995. Green pod culture of a therapeutically important species Dactylorhiza categoria (D.Don) Soo. The journal of the Orchid Society of India 9:7-12.

Warghat, A.R., Bajpai, P.K., Murkute, A.A., Sood, H., Chaurasia, O.P., and Srivastava, R.B. 2012. Genetic diversity and population structure of Dactylorhiza hatagirea (Orchidaceae) in the cold desert Ladakh region of India. Journal of Medicinal Plants Research 6(12):2388-2395.

Warghat, A.R., Bajpai, P.K., Srivastava, R.B., Chaurasia, O.P. and Sood, H. 2013. Population gennetic structure and conservation of small fragmented location of Dactylorhiza hatagirea in Ladakh region of India. Scientia Horticulturae 164:448-454

Warghat, A.R., Bajpai, P.K., Srivastava, R.B., Chaurasia, O.P., Chauhan, R.S., and Sood, H. 2014. "In-vitro protocorm development and mass multiplication of an endangered orchid, Dactylorhiza hatagirea."Turkish Journal of Botany 38:737-746.

Watanabe, T., Rajbhandari, K.R., Malla, K.J., and Yahara, S. 2005. A Handbook of Medicinal Plants of Nepal. Kobfai Publishing Project, Foundation for Democracy and Development Studies, Bangkok.

World Checklist of Selected Plant Families: Royal 
Nepal Journal of Science and Technology (NJST) (2020), 19(1)

Botanic Gardens, Kew. 2013. https://www.uv.mx/ personal/mgamez/files/2013/08/croton-checklistalumnos.pdf

Wray, G.A., 2007. The evolutionary significance of cisregulatory mutations. Nature Reviews Genetics 8:206-216.

Xie, J.H., Jin, M.L., Morris, G.A., Zha, X. Q., Chen, H.Q., Yi, Y., Li, J.E., Wang, Z.J., Gao, J., Nie, S.P., Shang, P. and Xie, M.Y. 2016. Advances on Bioactive Polysaccharides from Medicinal Plants. Critical Reviews in Food Science and Nutrition 56
(1)60-84.

Yam, T.W., Arditti, J., and Cameron, K M., 2009. "The orchids have been a splendid sport" - an alternative look at Charles Darwin's contribution to orchid biology. American Journal of Botany 96:21282154.

Yang, H.S., Han, D.K., Kim, J.R. and Sim, J.C. 2006. Effect of alpha-tocopherol on cadmium inducedtoxicity in rat testis and carcinogenesis. Journal of Korean Medical Science 21 (3):445-51. 